\title{
MEĐUJEZIČNI UTJECAJ ENGLESKOGA JEZIKA NA OVLADAVANJE TALIJANSKIM I FRANCUSKIM JEZIKOM U OSNOVNOJ ŠKOLI
}

\author{
Irena Vučićn \\ Osnovna škola Vladimira Nazora, Zagreb
}

\begin{abstract}
Ovaj se rad bavi istraživanjem međujezičnog utjecaja engleskoga jezika na ovladavanje talijanskim i francuskim jezikom. Cilj rada bio je ispitati povezanost i utjecaj engleskog kao prvog stranog jezika na usvajanje talijanskog i francuskog kao drugog ili trećeg stranog jezika s ciljem poticanja višejezičnosti povezivanjem postojećih znanja iz engleskog jezika na talijanski i francuski jezik. U središtu su ispitivanja dvije skupine učenika u osnovnim školama kojima je materinski jezik hrvatski (J1), prvi strani jezik engleski (J2), te drugi (J3) i treći (J4) strani jezik talijanski i francuski koje uče simultano od 4. razreda. $U$ istraživanju su sudjelovali učenici šestih, sedmih $i$ osmih razreda. Dobiveni su različiti rezultati kod učenika koji uče engleski i talijanski i onih koji uče još i francuski jezik. Rad je poslužio i kao poticaj na istraživačko i samostalno učenje s ciljem razvijanja međujezične i metajezične svjesnosti i cjeloživotnog učenja u okvirima nove obrazovne reforme.
\end{abstract}

Ključne riječi: međujezični utjecaji, proi, drugi i treći strani jezik, višejezičnost, sličnice, međujezična $i$ metajezična svjesnost, međujezik, istraživačko i cjeloživotno učenje.

\section{UVOD}

Motivacija za ovaj rad proizišla je iz dugogodišnjeg rada autorice u osnovnoj školi tijekom kojeg su se često mogli uočiti međujezični utjecaji kod višejezičnih učenika. Njihove su reakcije na poticanje uspoređivanja jezika bile uvijek pozitivne i dobro prihvaćene na satu. Često se na taj način uspjelo olakšati razumijevanje novih sadržaja u talijanskom i francuskom jeziku jer su im postali bliži i manje apstraktni.

Na ovladavanje novim jezikom utječe prvi strani jezik kojim je netko već ovladao, a mogu utjecati i različiti drugi jezici kojima osoba vlada jer se pri učenju stranoga jezika potiče cjelokupno jezično iskustvo stečeno usvajanjem materinskoga i učenjem i usvajanjem ostalih jezika. Postoji načelno pravilo da je sve veći broj jezika sve lakše učiti. U tome posebnu ulogu igraju srodni jezici koji omogućuju djelomično razumijevanje i mogu imati povoljnu ili nepovoljnu ulogu (pozitivni i negativni prijenos) (Jelaska, 2005: 102).

irenavucic7@gmail.com 
Prema novijim spoznajama i promijenjenim društvenim shvaćanjima o jezicima, umjesto naziva dvojezičnost ili bilingvalnost, mnogojezičnost ili multilingvalnost, sve se više širi naziv višejezičnost ili plurilingvalnost čime se želi istaknuti važnost poznavanja više od jednog stranog jezika.

\subsection{Povijesni pregled jezičnih dodira engleskog, talijanskog i francuskog jezika}

Jezične dodire engleskog, talijanskog i francuskog jezika razmatramo kao rezultat povijesnih i kulturoloških dodira različitih naroda tijekom stoljeća. Porijeklo engleskog jezika prati se uglavnom od 5. stoljeća poslije Krista kada su germanska plemena potisnula keltska, preostala od rimske vladavine, $u$ današnje pokrajine Wales i Škotsku te na otok Irsku. Skupina „,anglosaskih“ narječja postupno se razvila u staroengleski, mješavinu germanskih dijalekata s utjecajem latinskog i keltskog jezika. Smatra se da nešto manje od polovice riječi u engleskom jeziku ima svoje korijene u staroengleskom. Utjecaj su ostavili Vikinzi, zatim Normani tijekom osvajanja Engleske 1066. godine kada je francuski preuzet kao jezik dvorova, administracije i književnosti. Gramatičari toga razdoblja zanemarivali su ga, zbog čega je postao gramatički jednostavniji. Srednjoengleski je u tom periodu postao jezik neobrazovanog puka te se razvijao uz francuski jezik punih osamdeset godina. U to je vrijeme u engleski jezik ugrađeno oko 10000 francuskih riječi od čega su tri četvrtine i danas u uporabi. Oko jedne trećine svih riječi u engleskom jeziku potječe izravno ili neizravno iz francuskog i procjenjuje se da govornici engleskog jezika koji nisu nikad učili francuski jezik već poznaju 15000 riječi. Postoji više od 1700 riječi koje su istovjetne u oba jezika (engl. true cognates) (ThoughtCo ${ }^{1}$ ).

U Italiji su i izvan nje u kasno doba Rimskog Carstva nastajale razne vulgarno-latinske varijante ili narodni jezici koji su predstavljali općenit naziv za svaki latinski različit od službenog latinskog. Od romanskih jezika, talijanski je najbliži praocu - latinskom koji je u prošlosti imao snažan utjecaj na engleski jezik (Tekavčić, 1970). Tijekom stoljeća su ti jezici iskoristili veliki broj latinskih riječi koje su usvojili ili prilagodili (npr. Mass Media, Summit, Tutor, Audit, Forum, Sponsor, Auditorium). Renesansa, koja je započela u Italiji i stigla do Engleske preko Francuske, bila je izvor novog rječnika, i za engleski i za francuski jezik (Enciclopedia dell'italiano, 2010.2).

S leksičkog gledišta, utjecaj latinskog je vrlo očit, što su učenici primijetili uspoređujući ta tri jezika i uočavajući činjenicu da dijele određene sličnosti na leksičkoj razini zahvaljujući, među ostalim, neprestanim kontaktima među tim trima jezicima tijekom stoljeća.

\footnotetext{
${ }^{1}$ https://www.thoughtco.com/how-french-has-influenced-english-1371255

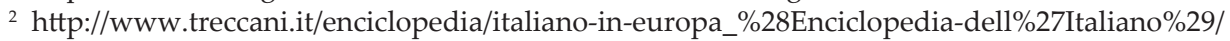




\subsection{Pogledi na višejezičnost u Hrvatskoj i Europi}

Višejezičnost je jedan od glavnih ciljeva jezične politike Europske unije te sve više dobiva na važnosti, čemu pridonose čimbenici kao što su globalizacija i internacionalizacija.

Dok gospodarstvo u Europi briše granice jezika i udružuje se, u kulturi i obrazovanju teži se za jezičnom raznolikošću prema kojoj bi svi stanovnici Europe trebali biti otvoreni zbog ostvarenja kvalitetnog suživota. U prošlosti je u nekim društvima upotreba više od jednog jezika većinom bila ograničena na posebne društvene slojeve, a u suvremenim društvima upotreba više od jednog jezika sve se više širi na cijelo društvo i postaje bitna neovisno o blizini neke zemlje s granicom druge zemlje. U pojedinim su razdobljima strani jezici bili i službeni jezici u Hrvatskoj pa su Hrvati oduvijek bili prisiljeni učiti i druge jezike (Jelaska, 2005: 277).

S ciljem poboljšanja društvene, kulturne i ekonomske suradnje, Vijeće Europe je 2002. godine dalo preporuku da svako dijete treba uz svoj, materinski, naučiti još dva strana jezika. Također, na sastanku Vijeća Europe 14. prosinca 2017. godine (Zaključci: Obrazovanje i kultura: 3) iznosi se preporuka za poboljšanje učenja jezika kako bi više mladih govorilo barem dva europska jezika uz materinski, čime bi se povećao protok radne snage, odnosno poboljšale mogućnosti zapošljavanja i dodatno izbjegla eventualna diskriminacija na jezičnoj osnovi. Tako se već od 1980-ih godina prošlog stoljeća u okviru brojnih projekata (Socrates, Leonardo da Vinci, Lingua, Erasmus, Comenius, Grundtvig) potiče razmjena učenika, studenata i profesora $\mathrm{s}$ ciljem usavršavanja jezika ponajprije $\mathrm{u}$ njihovu izvornom okruženju.

U Hrvatskoj je, među prvima, interes za to područje iskazala Maja Häusler (2000) koja naglašava upravo ulogu engleskog jezika u izgradnji višejezičnosti. Engleski kao temeljni strani jezik u školama mora kod učenika pobuditi znatiželju i volju za učenjem drugih jezika te time postati temelj razvoja višejezičnosti.

Istraživanje Mihaljević Djigunović (2013) pokazuje da višejezične osobe posjeduju pozitivniji stav prema učenju stranog jezika, kao i toleranciju prema ostalima jer takve osobe stvaraju više novih identiteta.

Školske godine 2003./2004. u Hrvatskoj se uvodi obvezno učenje prvoga stranog jezika od prvoga razreda osnovne škole. Za većinu učenika prvi je strani jezik engleski, a drugi je strani jezik njemački, talijanski ili francuski koji se mogu odabrati kao izborni predmeti u četvrtom razredu osnovne škole. U Istri se zbog hrvatsko-talijanske dvojezičnosti uči talijanski jezik kao izborni predmet od 2. razreda.

Novi kurikuli stranih jezika, primjerice Nacionalni kurikulum nastavnoga predmeta Talijanski jezik (2019), temelje se na suvremenim pristupima učenju i poučavanju. Cilj je učenja i poučavanja ponajprije razvoj 
komunikacijske kompetencije s pomoću koje će učenik zadovoljiti svoje temeljne potrebe i interese $u$ društvenim interakcijama. Takav funkcionalni pristup u nastavi stranih jezika poticao je David Wilkins još od 1973. godine.

U školama se potiče višejezičnost projektima koji se provode u okviru pojedinih jezika koje učenici uče u školi te izletima u zemlje čiji se jezik uči. Hrvatska se svake godine uključuje u projekt obilježavanja Europskog dana jezika (od 2001. godine) nizom raznovrsnih školskih aktivnosti kako bi se učenike osvijestilo o važnosti učenja stranih jezika.

Jedan od najvećih problema s drugim stranim jezikom u našim školama je u tome što nema vertikalne zastupljenosti toga jezika od vrtića do fakulteta što znači da provođenje jezične politike još uvijek nije zaživjelo, ponajprije zbog spomenutog nepostojanja kontinuiteta učenja. Učenici često nemaju priliku nastaviti učenje toga jezika na sljedećoj višoj razini obrazovanja, bilo $u$ srednjoj školi ili na fakultetima. Izbornost drugog stranog jezika u osnovnim školama zasad rezultira velikom stopom ispisivanja u petom, šestom i sedmom razredu.

Francuski jezik je, uz engleski, radni jezik Europske unije, jezik brojnih europskih institucija i međunarodnih organizacija. U hrvatskim školama posljednjih desetak godina sve se manje uči. Jezik koji je u EU među najkorisnijima, tek je na četvrtom mjestu interesa naših učenika, nakon sveprisutnog engleskog te njemačkog i talijanskog jezika. Mnogi ga učenici smatraju teškim i kažu da zahtijeva mnogo truda i učenja. Prema podacima Eurydicea 2017. ${ }^{3}$ godine, francuski je drugi strani jezik koji se najviše uči u EU. Ipak su optimistični podaci Eurostata iz 2015. ${ }^{4}$ godine prema kojima 59 \% europskih srednjoškolaca uči dva strana jezika, dok je u Hrvatskoj prosjek daleko nadmašen: dva strana jezika uči čak 93 \% hrvatskih srednjoškolaca.

\section{MEĐUJEZIČNI UTJECAJ I MEĐUJEZIK U KONTEKSTU VIŠEJEZIČNOSTI}

Jajić Novogradec (2017), nakon sveobuhvatnoga uvida u relevantnu literaturu, zaključuje da su se prva ozbiljna promišljanja o međujezičnim utjecajima pojavila u još 19. stoljeću, iako se termin "međujezični utjecaj" (engl. crosslinguistic influence) prvi puta spominje tek 1980. Prema Ilomaki (2005 u Jajić Novogradec, 2017: 46), već su se u prijašnjim istraživanjima upotrebljavali izrazi „koji su se odnosili na isti fenomen, poput: jezični prijenos (engl. language transfer), interferencija (engl. interference), miješanje jezika (engl. language mixing), utjecaj i uloga materinskog jezika (engl. influence and role of the mother tongue) “. Budući da se kontrastivna analiza

\footnotetext{
${ }_{3}^{3}$ https://op.europa.eu/en/publication-detail/-/publication/ff10cc21-aef9-11e7-837e-01aa75ed71a1/language-hr/format-PDF

${ }^{4}$ https://www.srednja.hr/zbornica/hrvatski-srednjoskolci-vrhu-eu-a-po-ucenju-stranih-jezika-necete-vjerovati-koliko-ih-uci-minimalno-dva/
} 
nije pokazala uspješnom metodom $u$ analizi učeničkih pogrešaka, početkom 1970-ih godina 20. stoljeća zamjenjuje ju analiza pogrešaka čiji fokus nije bio samo odgonetnuti korijene učeničkih pogrešaka na temelju usporedbe dvaju jezika (materinskog i stranog), nego i objasniti jezične procese koji su doveli do pojave pogrešaka u učenikovu jeziku. Istovremeno, istraživanja Selinkera (1972) dovode do razvijanja pojma međujezika (engl. interlanguage), odnosno jezika koji se sustavno razvija kako korisnik napreduje u svome ovladavanju inim jezikom (Medved Krajnović, 2010: 24). U istraživačkim krugovima sve su više prisutni nazivi „učenikov jezik“ (engl. learner language) i „,korisnikov jezik" (engl. user language). U kontekstu rasprave o navedenim pojmovima, često se spominje i pojam međujezične interakcije (engl. crosslinguistic interaction) koji Herdina i Jessner (2002: 29) smatraju „krovnim terminom za sve postojeće fenomene prijenosa" pa tako u njega uključuju ne samo pojmove "prijenos" i „interferencija“ nego i "miješanje kodova" te "posuđivanje“, ali i „nepredviđene dinamične učinke koji određuju razvoj samih sustava i osobito se zamjećuju u području višejezičnosti“.

Višejezični učenici ponekad i sami, nesvjesno pokušavaju odgonetnuti značenje u nekom stranom jeziku i oslanjaju se na inojezično znanje u drugim jezicima, tj. „transkomuniciraju“, pri čemu nastaje njihov jezik ili međujezik. Svjesni su da je engleski prvi svjetski jezik kojem su svakodnevno izloženi što im omogućuje da ga nesvjesno usvajaju za razliku od drugog stranog jezika.

\subsection{Višejezični pristup u nastavi}

Lujić (2017: 29 prema Py, 2007: 93) definira višejezični pristup kao povezivanje jezika u nastavi čiji je cilj razvoj višejezične komunikacijske kompetencije. Za razliku od jednojezičnog nastavnog pristupa koji se temelji na načelu razdvajanja jezika, višejezični pristup temelji se na ideji da je potrebno „stvarati i usmjeravati višesmjerne međujezične dodire: dodire između prvog i drugog jezika, dodire između učenika i izvornog govornika drugog jezika, dodire između više kultura", tj. učenicima dopustiti i potaknuti ih na korištenje njihova cjelokupnog komunikacijskog repertoara.

Europski centar za moderne jezike (European Centre for Modern Languages - ECML ${ }^{5}$ u Grazu, čija je uloga promovirati inovativne pristupe u učenju i poučavanju suvremenih jezika, organizira stručna usavršavanja CARAP (Cadre de Référence pour les Approches Plurielles des Langues et des Cultures I FREPA (A Framework of Reference for Pluralistic Approaches to Languages and Cultures). Europski centar za moderne jezike ističe da se metodologijom poučavanja jezika tijekom posljednjih trideset godina promiču sljedeća četiri pluralistička pristupa:

\footnotetext{
5 www.ecml.at
} 
- „buđenje svijesti o jezicima“ (engl. awakening to languages)

- međurazumijevanje između srodnih jezika (engl. intercomprehension between related languages)

- međukulturalni pristup (engl. intercultural approach), osim ovladavanja određenim jezičnim značajkama učenici moraju usvajati i sociokulturalno znanje

- integrirani didaktički pristup različitim jezicima (engl. integrated didactic approach to different languages) koji nadopunjuje redovnu nastavu stranih jezika.

Tim se pristupima razvijaju interes i pozitivan stav prema višejezičnosti, a obilježava ih povezivanje jezika i kultura. Pluralistički pristupi jezicima i kulturama stoga uključuju uporabu nekoliko (ili barem više od jednoga) jezika ili kultura istovremeno za razliku od „pojedinačnih“ pristupa u kojima didaktički pristup podrazumijeva samo jedan jezik ili određenu kulturu (Candelier i sur., 2012: 6).

Prema Zajedničkom europskom referentnom okviru za jezike (2005), dokumentu koji se pojavljuje u Europi temeljem izrade sveopćeg kurikula u jezično-komunikacijskom području za pojedine strane jezike, višejezični pristup podrazumijeva stvaranje zajedničke komunikacijske kompetencije svih jezika učenika i stalnu interakciju među njima. Stoga se i cilj jezičnog obrazovanja mijenja i ne obuhvaća više ovladavanje jednim ili dvama, čak i trima jezicima zasebno, već obuhvaća stvaranje jezičnog repertoara u kojem sve jezične sposobnosti dolaze do izražaja. U skladu s takvim najnovijim jezikoslovnim spoznajama o odnosu među različitim jezicima govornika koji znaju dva ili više jezika smatra se da su jezici kojima pojedinac govori međusobno isprepleteni i djeluju jedni na druge čineći njegovu komunikacijsku sposobnost bogatom. Oni su povezani u njegovu umu bez obzira na način kako ih je, gdje i kada stekao. Različiti jezici višejezičnoga govornika međuodnosom stvaraju jezične sposobnosti koje su šire od pukoga zbroja jezičnoga znanja i jezičnih sposobnosti svakoga pojedinoga jezika koji zna te se u sporazumijevanju služi svojim najraznolikijim jezičnim sposobnostima utemeljenjima na znanju svih jezika.

$\mathrm{U}$ prošlosti su u metodologiji poučavanja jezika bile popularne razne metode: gramatičko-prijevodna metoda, direktna, različite audiovizualne i audiolingvalne metode. Ni jedna se od njih danas ne upotrebljava u čistom obliku, ali elementi svake od njih ulaze u naše modele nastave stranog jezika (Prebeg Vilke, 1977: 157). Stoga suvremena didaktika odbacuje svaku vrstu krutoga, dogmatskog pristupa nastavi i omogućava nastavniku da kombinirajući postupke iz različitih metodičkih sustava kreira metodu koja najviše odgovara potrebama učenika. Tako se upotreba engleskog jezika $u$ poučavanju talijanskog i francuskog pokazala vrlo učinkovitom i poticajnom 
za učenike zbog razvijanja samopouzdanja i pozitivnog stava prema učenju stranog jezika u čiji su proces na taj način aktivno uključeni.

U istraživanju koje je provela Lujić (2017: 184) potvrđena je pretpostavka da će višejezičnim učenicima više odgovarati višejezični pristup nego jednojezični, u kojem su češće sudjelovali na vlastiti poticaj. Lujić (ibid.) ističe da su „sličnosti i razlike među trima jezicima važan element koji bi trebao utjecati na izradu nacionalnih i školskih jezičnih politika te bi upravo jezična udaljenost trebala biti čimbenik koji će utjecati na omjer izloženosti učenika različitim jezicima u kurikulu u smislu intenziteta, ali i optimalne dobi za početak učenja jezika“.

\subsection{Nova shvaćanja učeničkih pogrešaka}

Medved Krajnović (2010) ukazuje na novija istraživanja učeničkih pogrešaka na koje se ne gleda više kao na "loše navike“ koje treba iskorijeniti već da bi njihova uloga trebala biti iskorištavanje postojećih znanja svih jezičnih sustava kojima pojedinac vlada i tako proširivanje njihove primjenjivosti i na učenje dodatnih jezika. U skladu s tim, Medved Krajnović (ibid.) ističe da se trebaju tražiti i dodatna objašnjenja pogrešaka. Pogreške i njihova pojašnjenja važna su nastavnicima, ali i učenicima jer se njihove pogreške mogu promatrati kao sredstvo kojim se učenici služe dok uče i, naposljetku, istraživača kojima je namjera prikupiti podatke o prirodi učenja i usvajanja jezika te kojim se strategijama služe učenici pri učenju ciljnoga jezika. Medved Krajnović (ibid.) nadalje naglašava da se količina međujezičnih utjecaja ne smanjuje nužno s porastom jezičnoga znanja u inome jeziku zbog različitih vrsta jezičnog prijenosa i brojnih individualnih čimbenika. $U$ istraživanju koje se prikazuje u ovom radu, učenici koji uče talijanski jezik u zadacima prevođenja često su dodavali nastavak -to kod imenica i pridjeva (npr. umjesto importante importanto, società - sociato, parte - parto), što nastavniku može biti koristan podatak za daljnja istraživanja ovladavanja talijanskim jezikom. Medved Krajnović (ibid.) napominje da je kod nastavnika još nedovoljno osviještena mogućnost upućivanja učenika na sve one elemente u kojima su njihov prvi i strani jezik slični. Ističe da, osim jezičnog prijenosa prema naprijed i prema natrag, postoji i dvosmjerni prijenos (engl. bidirectional transfer) kada dva jezika istovremeno utječu jedan na drugi, koji je ujedno i najkarakterističniji u kontekstu višejezičnosti.

Zanimljivo je mišljenje Pavličević Franić (2006: 6) da je pogreška, čiji naziv valja razumjeti uvjetno, znak da dijete zna „lingvistički misliti“ jer je jednom naučeno pravilo poopćilo i primijenilo na druge naoko istovrsne dijelove sustava te da ima izrazito stvaralački odnos prema jeziku kao sustavu. 


\subsection{Promišljanja $i$ istraživanja o međujezičnim utjecajima}

Meissner (2004: 49) predlaže nekoliko modela prijenosa koji bi trebali pružiti pozitivan učinak na ovladavanje novim jezikom kod pojedinca: nastavnici bi učenike trebali osvještavati o sličnostima i razlikama, prije svega između materinskog i stranog jezika, osobito na početnim stupnjevima učenja, a zbog sustavnosti materinskog jezika. Osoba će graditi svoje jezične djelatnosti posredstvom i ostalih jezika, a međujezični prijenos uključuje i pozitivnu i negativnu korelaciju među jezicima. Stoga, neke gramatičke strukture mogu $\mathrm{u}$ jednom jeziku poslužiti kao pomoć $u$ ovladavanju sličnom strukturom $u$ drugom jeziku. Primjer koji potvrđuje tu tvrdnju je 6. zadatak u instrumentu za prikupljanje podataka koji je korišten $u$ istraživanju prikazanom $u$ ovom radu (v. priloge 1 i 2), u kojem su se učenici trebali na talijanskom i/ili francuskom prisjetiti strukture koja odgovara engleskoj there is/there are, a uz pomoć koje brže mogu razumjeti tražene strukture c'èlci sono i il y $a$. U istom su zadatku povezujući dva engleska i dva talijanska oblika prezenta bolje shvatili razliku između Io vado i Io sto andando. Meissner (ibid.) također naglašava da poznavanje jednog romanskog jezika olakšava ovladavanje ostalim romanskim jezicima te ističe njihovu dinamičnost, odnosno stalnu interakciju.

Klein (2008), u članku L'anglais, base possible de l'intercompréhension romane?, također ističe da engleski jezik sadrži dovoljno romanskih elemenata koji mogu poslužiti kao jezični prijenos za učenike koji posjeduju minimalno znanje barem jednog romanskog jezika. Tako je i prema Neuneru (2004) kod učenika potrebno raspravljati o sličnostima i razlikama među jezicima, jer njihovo nedovoljno ukazivanje može dovesti do netočne upotrebe novog jezika.

Dok se ranije na međujezični utjecaj gledalo kao na nešto što bi moglo imati isključivo negativan utjecaj na ovladavanje novim jezikom, recentnija su istraživanja usmjerena na proučavanje pozitivnog utjecaja. Hufeisen i Neuner (2004) ističu da postoji znatna razlika u ovladavanju J2 i J3, a nešto manja u ovladavanju J3 i J4 s obzirom na to da jezične vještine koje je učenik razvio u J2 olakšavaju proces ovladavanja J3 ili sljedećim novim jezikom. Letica i Mardešić (2007) ispituju međujezične utjecaje s obzirom na izloženost jeziku kao jednom od čimbenika. Kao glavni izvor utjecaja pokazao se hrvatski jezik, odnosno prvi jezik, zatim lagani utjecaj J2 na J3, ali nije bilo utjecaja J3 na J2. Kod sudionika koji su bili više izloženi J2 pokazalo se više utjecaja J2 i J1 na J3, a kod onih više izloženih J3 nije bilo prijenosa $u$ $\mathrm{J} 2$, te neznatnog prijenosa $\mathrm{J} 1 \mathrm{u} \mathrm{J} 3$, što može uputiti na redoslijed učenja kao izraženiji čimbenik u ovome primjeru.

Grzega (2005) je jedan od prvih lingvista koji se bavio međurazumijevanjem europskih jezika. U svom je radu The Role of English in Learning and Teaching European Intercomprehension Skills koji je proizišao iz istraživanja u 
okviru projekta EuroCom proučavao pojavu jezičnog prijenosa između engleskog i romanskih jezika. U radu, tj. projektu predlaže se pristup kojim se više jezika iz iste grupe može lako i brzo naučiti uz pomoć tzv. sedam sita, franc. sept tamis, koja mogu pomoći u procesu učenja jezika iz romanske grupe. U početnoj fazi učenja potrebno je pronaći: 1 . internacionalizme $u$ jeziku koji se uči, 2. romanizme, 3. glasove koji su podudarni, 4. pravila za čitanje i pisanje, 5. sintaktičke strukture koje su karakteristične za romanske jezike, 6. morfosintaktičke elemente karakteristične za romanske jezike, i 7. najčešće korištene prefikse i sufikse iz latinskog i starogrčkog.

Jajić Novogradec (2017: 109) opisuje istraživanje i zaključke Proverbio i sur.: „S neurolingvističkog stajališta, Proverbio i sur. (2006) istražuju jezičnu organizaciju slovensko-talijanskih dvojezičara, simultanih i konsekutivnih talijansko-engleskih prevoditeljai talijanskihjednojezičara.Istraživanjeautora $\mathrm{u}$ kojemu su ispitivali vrijeme reakcije i točnost pojedinih riječi u zadacima leksičke odluke u prvome i drugome jeziku, navelo ih je na zaključak da čim je više jezika uključeno u pojedinčev jezični repertoar, tim je sporije njihovo leksičko procesiranje, čak i u njihovom prvom jeziku, a to ne ovisi toliko o jezičnom znanju pojedinih jezika, koliko o dobi učenja pojedinog jezika“. Prema tim autorima, različiti se jezici ne smještaju odvojeno u mozgu, pa bi tu spoznaju vrijedilo provjeriti u daljnjim neuorlingvističkim istraživanjima.

De Angelis (2007) tvrdi da je slabo poznato kako višejezični govornici obrađuju i povezuju jezičnu informaciju iz tri ili više jezika istovremeno. Pretpostavlja se da su kognitivne radnje u višejezičara izrazito složene te stoga utječu na njihovo neobično ponašanje $u$ jezičnoj proizvodnji.

Cenoz (2001) istražuje učinak dobi na pojavu međujezičnih utjecaja. Njezina su istraživanja pokazala jednak stupanj međujezičnih utjecaja neovisno o dobi učenika, jer je njihovo jezično znanje J3 još uvijek ograničeno. $\mathrm{U}$ istraživanju koje se prikazuje u tom radu učenici svih razreda koristili su se svojim višejezičnim leksičkim znanjem neovisno o stupnju učenja pojedinog jezika. Učenici osmih razreda čak su u nekim zadacima postigli lošije rezultate od učenika nižih razreda.

Uočavanjem sličnosti i razlika među jezicima, učenici razvijaju višejezičnu svjesnost (engl. multilingual awareness). Jessner (2008: 279) ističe dvije vrste višejezične svjesnosti: međujezične i metajezične. Međujezičnu svjesnost definira kao „svjesnost interakcije među jezicima u višejezične osobe, dok metajezična svjesnost omogućuje njenu objektivizaciju“ za koju smatra da se „kod jednojezičnih osoba, za razliku od višejezičnih, pojavljuje u manjem obimu te da je po prirodi različita". Međujezično osvještavanje (engl. cross-linguistic work and awareness) kao nastavna tehnika $\mathrm{u}$ ovom istraživanju poslužila je za ukazivanje na međujezične sličnosti kako bi se učenicima omogućilo razvijanje jezične svjesnosti. 
Milambiling (2011) također govori o važnosti uključivanja više jezika koje učenik poznaje $u$ nastavu nekog drugog stranog jezika razvijajući metajezičnu svjesnost koja im olakšava učenje novog jezika, na što se u jednom dijelu fokusira i istraživanje koje se prikazuje u sljedećem poglavlju.

\section{ISTRAŽIVANJE}

\subsection{Ciljevi, istraživačka pitanja i hipoteze}

$\mathrm{U}$ istraživanju se nastojalo otkriti u kojoj mjeri znanje engleskog jezika utječe na jezično znanje talijanskog i francuskog kod dvije skupine učenika, onih koji uz engleski uče samo talijanski i kod onih koji uz talijanski uče još i francuski te u kojoj će mjeri obje skupine razviti međujezičnu i metajezičnu svjesnost nakon rješavanja zadataka, tj. koliko će svjesno i postupno kontrolirati upotrebu engleskog, talijanskog i francuskog jezika tijekom rješavanja upitnika.

Iz navedenoga cilja proizlaze sljedeća istraživačka pitanja i hipoteze:

1. Hoće li znanje engleskog jezika biti više povezano s pojavom međujezičnih utjecaja kod učenika koji uče samo talijanski ili kod onih koji uče talijanski i francuski jezik?

H: Rezultati će biti slični kod učenika koji uče engleski i talijanski kao i kod onih koji uče još i francuski jezik.

2. U kojoj su mjeri obje skupine razvile međujezičnu i metajezičnu svjesnost o sličnosti jezika koje uče nakon rješavanja zadataka?

H: Svi će učenici podjednako razviti međujezičnu i metajezičnu svjesnost jer će nakon pomoći i vođenja u rješavanju zadataka, uz pomoć ponuđenih nastavaka, svjesnije kontrolirati jezičnu uporabu.

\subsection{Instrument}

Instrument $\mathrm{u}$ istraživanju sastoji se od sedam zadataka za prvu skupinu (v. prilog 1), odnosno osam zadataka za drugu skupinu učenika (v. prilog 2).

Međujezični su se utjecaji ispitivali uglavnom zadacima prijevoda $\mathrm{s}$ engleskog na talijanski i francuski jezik, što čini jednu od glavnih istraživačkih metoda $\mathrm{u}$ ispitivanjima međujezičnih utjecaja. Budući da su međujezični utjecaji posebno vidljivi na leksičkoj razini, zadaci su se sastojali uglavnom od pravih, ali i djelomičnih sličnica, riječi čiji su oblik i značenje isti ili slični među jezicima i koje se mogu lako prepoznati u leksiku i koje mogu znatno olakšati proces ovladavanja jezikom. Osim sličnosti na leksičkoj razini, uspoređivale su se i određene gramatičke strukture. 


\subsection{Sudionici i provedba istraživanja}

Istraživanje je provedeno $u$ dvije osnovne škole, od kojih se $u$ jednoj uči još i francuski jezik.

Sudionike $\mathrm{u}$ istraživanju činile su dvije skupine učenika šestih, sedmih i osmih razreda: oni koji uče talijanski kao drugi strani jezik $(\mathrm{N}=85)$ te oni koji uče još i francuski $(\mathrm{N}=16)$. Nakon odobrenja ravnatelja škole o provedbi istraživanja, učenicima su podijeljene suglasnosti koje su roditelji potpisali ukoliko su pristali da njihovo dijete sudjeluje u istraživanju.

Nastavnik je pažljivo u svakom razredu pratio istraživanje vodeći računa o pravovremenom dijeljenju zadataka na odvojenim listićima kako bi se što više potaknulo učenike na samostalno istraživanje i uspoređivanje jezika prije dobivenog rješenja. Nakon svakog riješenog zadatka učenici su mogli provjeriti točnost odgovora na novom dobivenom listiću uz pomoć novih riječi, ali s istim nastavkom, čime su svjesno povezivali riječi u sva tri jezika i uočavali njihove sličnosti i razlike.

U okviru zadataka za učenike prve skupine, u sedmom se pitanju tražilo da procijene sličnost engleskog i talijanskog, a u osmom pitanju za učenike druge skupine da osim sličnosti engleskog i talijanskog dodatno procijene i sličnost engleskog i francuskog te francuskog i talijanskog jezika. Učenici koji uče još i francuski jezik riješili su jedan zadatak više jer su se trebali prisjetiti francuske strukture „il y a“ uz pomoć engleskog i talijanskog oblika istog glagola ponuđenog u prethodnom zadatku.

\subsection{Rezultati}

U prvom zadatku (koji su učenici dobili odvojeno od ostalih zadataka na radnom listiću) trebalo je identificirati riječi na engleskom jeziku koje imaju sličan oblik i na talijanskom jeziku. Svaku od osam riječi koje je trebalo identificirati učenici koji uče talijanski identificirali su češće nego učenici koji uče talijanski i francuski jezik. Najveće razlike među skupinama učenika pronađene su za riječ „part“ (69,4 \% za učenike koji uče talijanski, 25,0 \% za učenike koji uče talijanski i francuski). Najmanje su razlike kod riječi „important” (94,1 \% za tal., 93,8\% za tal. i fr.). Općenito su se najtežima za identifikaciju pokazale riječi „part“ i „,society," a najlakšima „information“ i „important“ (v. tablica 1. i slika 1.) 
Vučić: MeĐujezični utjecaj engleskoga jezika na ovladavanje... (str. 3-29)

Tablica 1. Broj točnih odgovora na zadatku identifikacije sličnih riječi na drugom jeziku za učenike koji uče talijanski $(N=85)$ te one koji uče talijanski i francuski jezik $(N=16)$

\begin{tabular}{lcccc}
\hline \multirow{2}{*}{ Riječi koje je trebalo identificirati } & \multicolumn{2}{c}{ Talijanski } & \multicolumn{2}{c}{ Talijanski i francuski } \\
\cline { 2 - 5 } & $\mathbf{n}$ & $\mathbf{\%}$ & $\mathbf{n}$ & $\mathbf{\%}$ \\
\hline 1. Society & 65 & $76,5 \%$ & 9 & $56,3 \%$ \\
2. Important & 80 & $94,1 \%$ & 15 & $93,8 \%$ \\
3. Part & 59 & $69,4 \%$ & 4 & $25,0 \%$ \\
4. To communicate & 79 & $92,9 \%$ & 12 & $75,0 \%$ \\
5. Information & 83 & $97,6 \%$ & 15 & $93,8 \%$ \\
6. Cultures & 76 & $89,4 \%$ & 13 & $81,3 \%$ \\
7. To visit & 78 & $91,8 \%$ & 14 & $87,5 \%$ \\
8. Possible & 78 & $91,8 \%$ & 11 & $68,8 \%$ \\
\hline
\end{tabular}

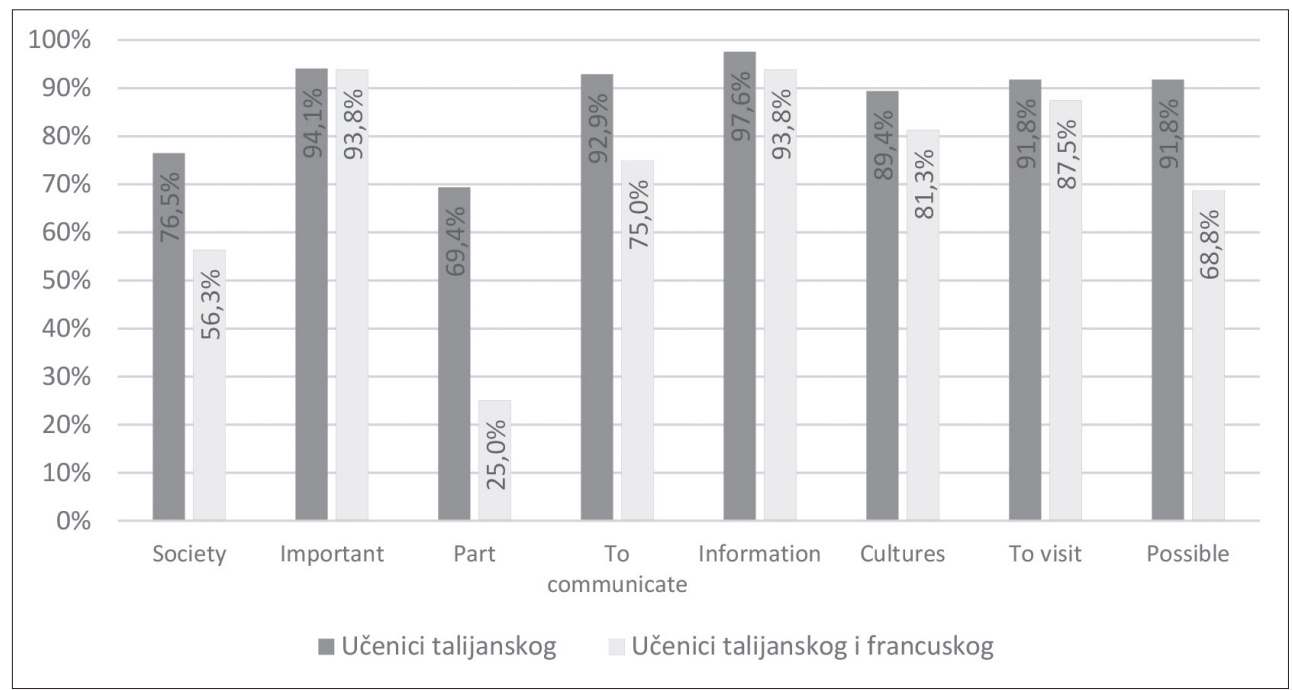

Slika 1. Grafički prikaz udjela točnih odgovora na zadatku identifikacije sličnih riječi na drugom jeziku

U drugom zadatku prijevoda riječi s poznatim nastavcima učenici koji uče talijanski ponovno postižu bolje rezultate za sve pojedine riječi od učenika koji uče talijanski i francuski. Najveće razlike među skupinama učenika opet su pronađene za riječ „part“ (47,1 \% za tal., 6,3\% za tal. i fr.). Također su ponovno nađene najmanje razlike kod riječi „important“ $(82,4$ $\%$ za tal., 75,0 \% za tal. i fr.). Najtežima su se za prijevod pokazale riječi „to communicate“ i „part,“ a najlakšima „important" i „to visit.“ Učenici koji uče talijanski i francuski uglavnom su postizali lošije rezultate pri prijevodu na francuski nego na talijanski, s iznimkama riječi „information“ (25,0 \% za prijevod na tal., 56,3 \% za prijevod na fr.) i „possible“ (31,3\% za prijevod na tal., $43,8 \%$ za prijevod na fr.) (v. tablica 2. i slika 2.). 
Tablica 2. Broj točnih odgovora na zadatku prijevoda riječi s poznatim nastavcima

\begin{tabular}{lcccccc}
\hline \multirow{2}{*}{$\begin{array}{l}\text { Riječi koje je trebalo } \\
\text { prevesti }\end{array}$} & \multicolumn{2}{c}{ Učenici talijanskog } & \multicolumn{4}{c}{ Učenici talijanskog i francuskog } \\
\cline { 2 - 7 } & \multicolumn{2}{r}{ Prijevod na talijanski } & \multicolumn{2}{c}{ Prijevod na talijanski } & Prijevod na francuski \\
\cline { 2 - 7 } & $\mathbf{n}$ & $\mathbf{\%}$ & $\mathbf{n}$ & $\mathbf{\%}$ & $\mathbf{n}$ & $\%$ \\
\hline 1. Society & 11 & $12,9 \%$ & 3 & $18,8 \%$ & 1 & $6,3 \%$ \\
2. Important & 70 & $82,4 \%$ & 12 & $75,0 \%$ & 4 & $25,0 \%$ \\
3. Part & 40 & $47,1 \%$ & 1 & $6,3 \%$ & 1 & $6,3 \%$ \\
4. To communicate & 23 & $27,1 \%$ & 2 & $12,5 \%$ & 0 & $0,0 \%$ \\
5. Information & 44 & $51,8 \%$ & 4 & $25,0 \%$ & 9 & $56,3 \%$ \\
6. Cultures & 48 & $56,5 \%$ & 6 & $37,5 \%$ & 4 & $25,0 \%$ \\
7. To visit & 59 & $69,4 \%$ & 9 & $56,3 \%$ & 1 & $6,3 \%$ \\
8. Possible & 55 & $64,7 \%$ & 5 & $31,3 \%$ & 7 & $43,8 \%$ \\
\hline
\end{tabular}

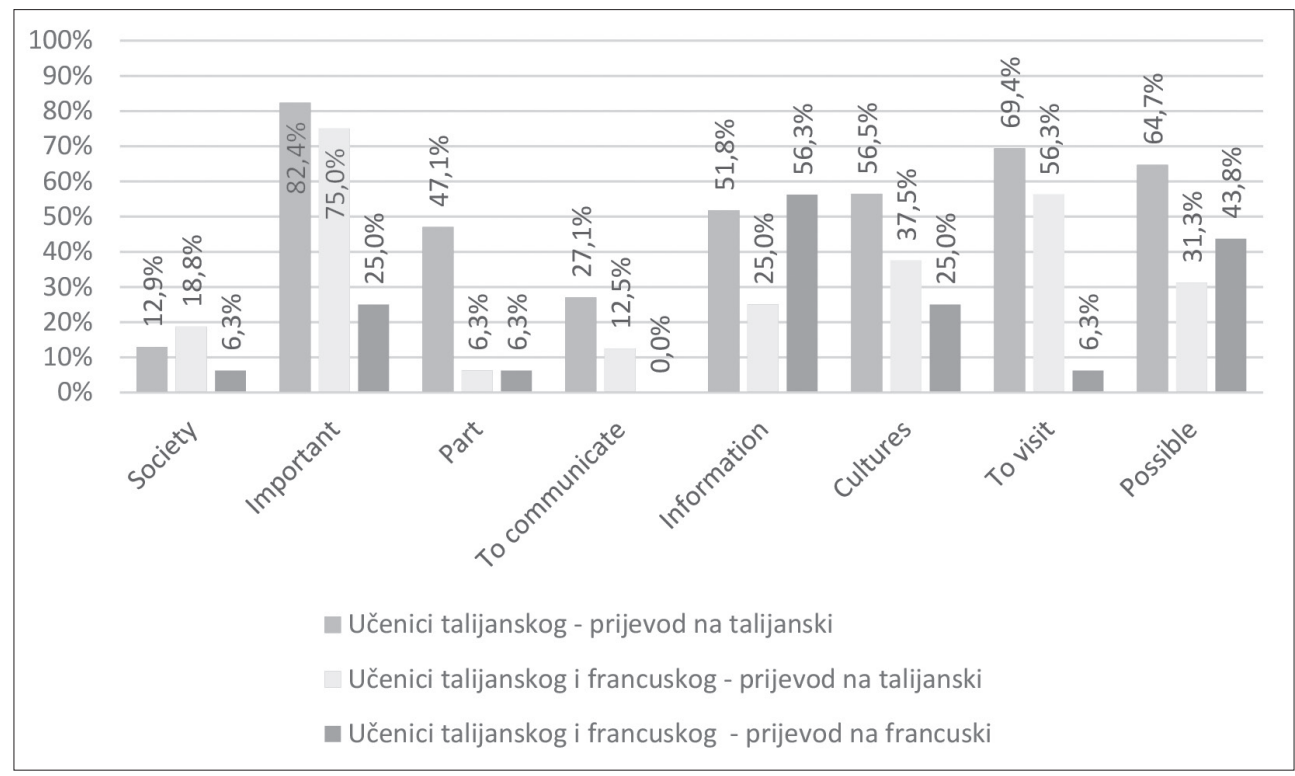

Slika 2. Grafički prikaz udjela točnih odgovora na zadatku prijevoda riječi s poznatim nastavcima

Kao i u prethodna dva zadatka, učenici koji uče talijanski na zadatku prijevoda s nepoznatim nastavcima postigli su bolje rezultate na prijevodu svake pojedine riječi od učenika koji uče talijanski i francuski. Najveće razlike u točnosti prijevoda opažene su kod riječi „excursion“ (38,8 \% za tal., 0,0 \% za tal. i fr.) koju nije točno preveo nijedan učenik koji uči talijanski i francuski, "geography“ (74,1 \% za tal., 31,3 \% za tal. i fr.) i „,television“ (68,2 \% za tal., 37,5 \% za tal. i fr.). Najlakša je za prijevod na talijanski bila riječ „,animal“ (97,6 \% za tal., $81,3 \%$ za tal. i fr.). Najteža je bila riječ „,communicative“ (24,7 \% za tal., $25,0 \%$ za tal. i fr.). Učenici koji uče talijanski i francuski ponovno su uglavnom postizali lošije rezultate pri prijevodu na francuski nego na talijanski, s iznimkama riječi „force“ (37,5 \% za prijevod na tal., 50,0 \% za prijevod na fr.), 
„excursion," s velikim porastom u udjelu točnih odgovora pri prijevodu na francuski (0,0 \% za prijevod na tal., 50,0 \% za prijevod na fr.), te ",action" (12,5 \% za prijevod na tal., 50,0 \% za prijevod na fr.) (v. tablica 3. i slika 3.).

Tablica 3. Broj točnih odgovora na zadatku prijevoda riječi s nepoznatim nastavcima

\begin{tabular}{lcccccc}
\hline \multirow{2}{*}{$\begin{array}{l}\text { Riječi koje je trebalo } \\
\text { prevesti }\end{array}$} & \multicolumn{2}{c}{ Učenici talijanskog } & \multicolumn{4}{c}{ Učenici talijanskog i francuskog } \\
\cline { 2 - 7 } & \multicolumn{2}{l}{ Prijevod na talijanski } & \multicolumn{2}{l}{ Prijevod na talijanski } & \multicolumn{2}{c}{ Prijevod na francuski } \\
\cline { 2 - 7 } & $\mathbf{n}$ & $\mathbf{0}$ & $\mathbf{n}$ & $\%$ & $\mathbf{n}$ & $\%$ \\
\hline 1. Animal & 83 & $97,6 \%$ & 13 & $81,3 \%$ & 11 & $68,8 \%$ \\
2. Force & 50 & $58,8 \%$ & 6 & $37,5 \%$ & 8 & $50,0 \%$ \\
3. Curious & 33 & $38,8 \%$ & 4 & $25,0 \%$ & 1 & $6,3 \%$ \\
4. Excursion & 33 & $38,8 \%$ & 0 & $0,0 \%$ & 8 & $50,0 \%$ \\
5. Geography & 63 & $74,1 \%$ & 5 & $31,3 \%$ & 2 & $12,5 \%$ \\
6. Extraordinary & 27 & $31,8 \%$ & 3 & $18,8 \%$ & 0 & $0,0 \%$ \\
7. Television & 58 & $68,2 \%$ & 6 & $37,5 \%$ & 5 & $31,3 \%$ \\
8. Communicative & 21 & $24,7 \%$ & 4 & $25,0 \%$ & 3 & $18,8 \%$ \\
9. Action & 43 & $50,6 \%$ & 2 & $12,5 \%$ & 8 & $50,0 \%$ \\
10. Professor & 62 & $72,9 \%$ & 8 & $50,0 \%$ & 5 & $31,3 \%$ \\
\hline
\end{tabular}

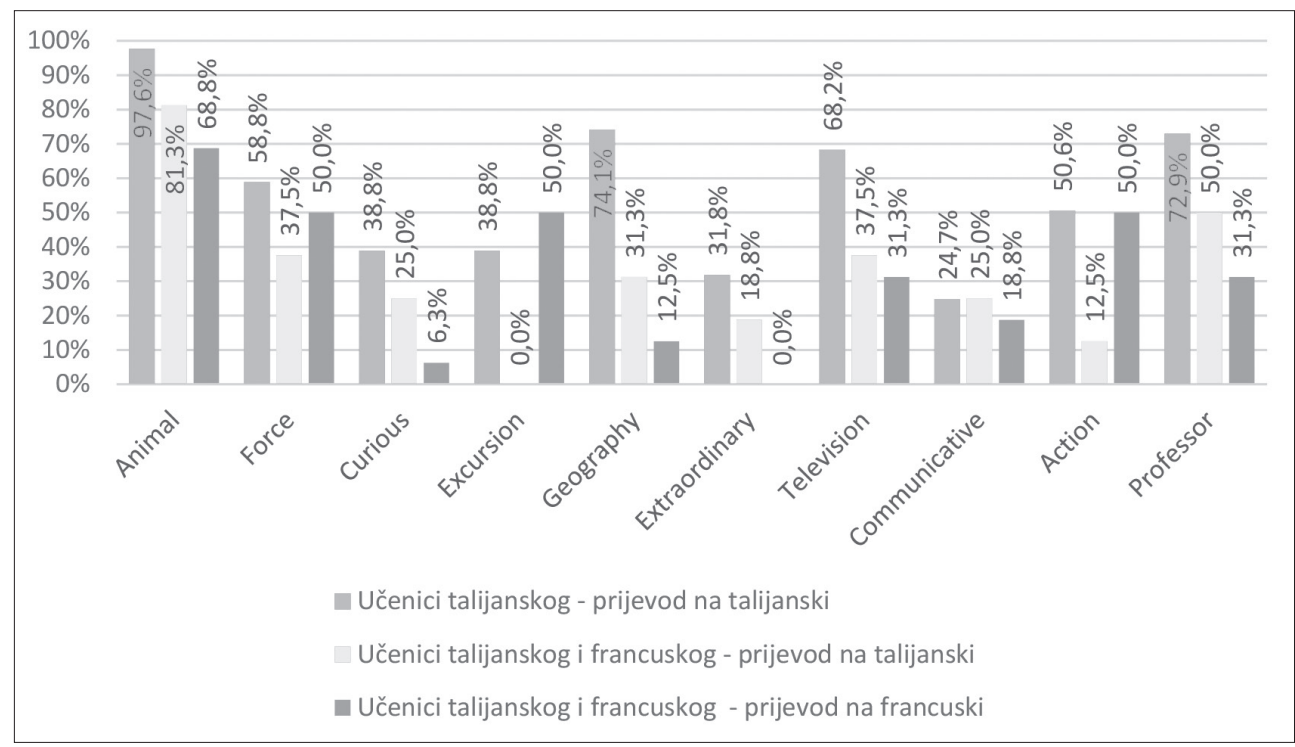

Slika 3. Grafički prikaz udjela točnih odgovora na zadatku prijevoda riječi s nepoznatim nastavcima

U petom zadatku, u kojemu su obje skupine trebale prevesti rečenice s talijanskog na engleski jezik, ponovno učenici koji uče samo talijanski postižu bolje rezultate pri prijevodu svih fraza od učenika koji uče talijanski i francuski. Različite fraze otprilike su ujednačene po tome koliko ih je lako bilo prevesti, te su i razlike među učenicima talijanskog te talijanskog $\mathrm{i}$ francuskog jezika otprilike jednake (v. tablica 4. i slika 4.). 
Tablica 4. Broj točnih odgovora na zadatku prijevoda fraza s talijanskog na engleski jezik

\begin{tabular}{lcccc}
\hline \multirow{2}{*}{$\begin{array}{l}\text { Fraze koje je bilo potrebno } \\
\text { identificirati }\end{array}$} & \multicolumn{2}{c}{ Talijanski } & \multicolumn{2}{c}{ Talijanski i francuski } \\
\cline { 2 - 5 } & $\mathbf{n}$ & $\mathbf{\%}$ & $\mathbf{n}$ & $\%$ \\
\hline 1. C'è & 76 & $89,4 \%$ & 11 & $68,8 \%$ \\
2. Ci sono & 75 & $88,2 \%$ & 12 & $75,0 \%$ \\
3. Sto parlando a & 70 & $82,4 \%$ & 11 & $68,8 \%$ \\
4. Parlo & 72 & $84,7 \%$ & 12 & $75,0 \%$ \\
\hline
\end{tabular}

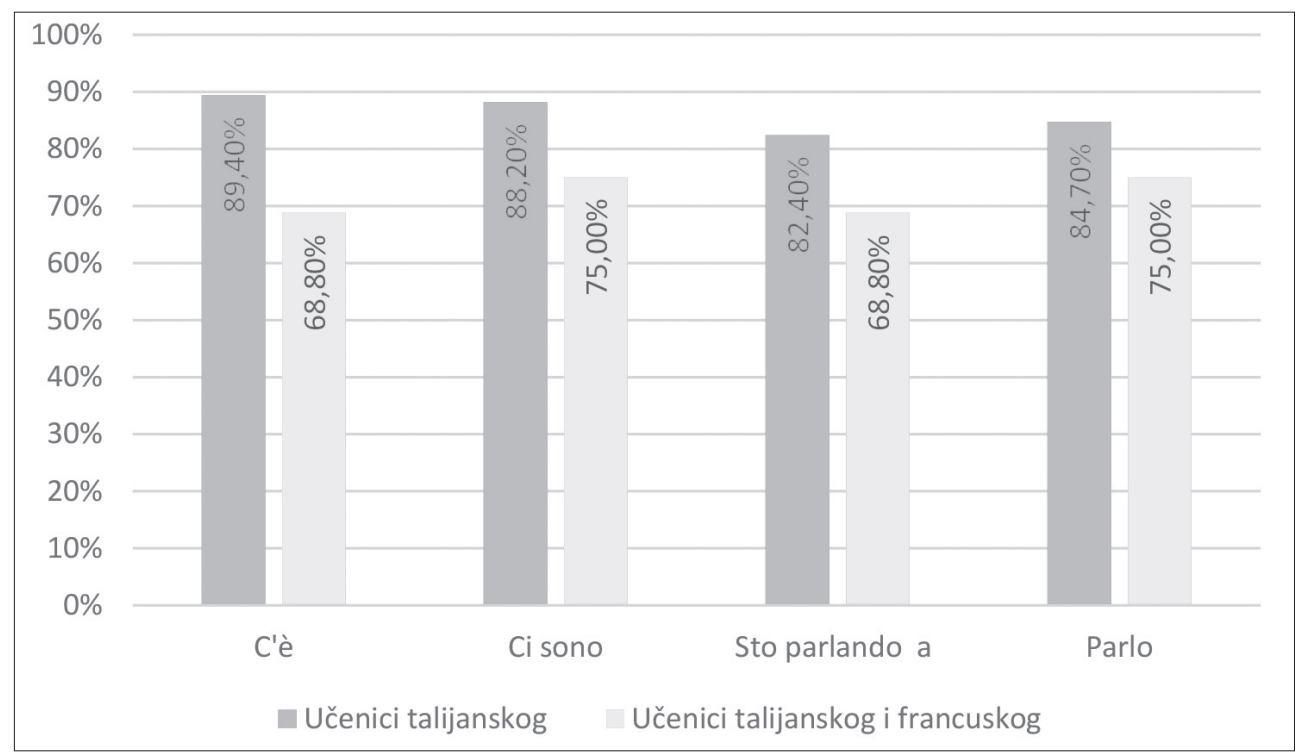

Slika 4. Grafički prikaz udjela točnih odgovora na zadatku prijevoda fraza s talijanskog na engleski jezik

U posljednjem pitanju, u procjenama sličnosti svih jezika koje učenici uče, najčešće je odabiran odgovor da su jezici slični. Odgovor da su jezici jako slični najčešće su birali učenici talijanskog i francuskog pri usporedbi engleskog i francuskog jezika $(37,5 \%)$ (v. tablica 5.).

Tablica 5. Zastupljenosti odgovora o sličnosti jezika

\begin{tabular}{|c|c|c|c|c|c|}
\hline \multirow{2}{*}{ Jezici su: } & & \multicolumn{2}{|c|}{ Usporedba engl. i tal. } & \multirow{2}{*}{$\begin{array}{l}\text { Usporedba } \\
\text { engl. i fr. }\end{array}$} & \multirow{2}{*}{$\begin{array}{l}\text { Usporedba fr. } \\
\text { i tal. }\end{array}$} \\
\hline & & Uče tal. & Uče tal. i fr. & & \\
\hline \multirow{2}{*}{ Potpuno različiti } & $\mathrm{n}$ & 1 & 2 & 2 & 2 \\
\hline & $\%$ & 1,2 & 12,5 & 12,5 & 12,5 \\
\hline \multirow{2}{*}{ Različiti } & $\mathrm{n}$ & 12 & 0 & 0 & 0 \\
\hline & $\%$ & 14,6 & 0,0 & 0,0 & 0,0 \\
\hline \multirow{2}{*}{ Slični } & $\mathrm{n}$ & 67 & 11 & 8 & 9 \\
\hline & $\%$ & 81,7 & 68,8 & 50,0 & 56,3 \\
\hline \multirow{2}{*}{ Jako slični } & $\mathrm{n}$ & 2 & 3 & 6 & 5 \\
\hline & $\%$ & 2,4 & 18,8 & 37,5 & 31,3 \\
\hline \multirow{2}{*}{ Ukupno } & $\mathrm{n}$ & 82 & 16 & 16 & 16 \\
\hline & $\%$ & 100,0 & 100,0 & 100,0 & 100,0 \\
\hline
\end{tabular}


Ukupni rezultati na različitim zadacima izračunati su zbrajanjem pojedinačnih točnih odgovora, od kojih je svaki nosio jedan bod. Prema tome, na zadacima identifikacije i prijevoda s poznatim nastavcima raspon mogućih bodova kreće se od 0 do 8 , na zadatku prijevoda bez nastavaka od 0 do 10, a na zadatku prijevoda fraza od 0 do 4 . Za usporedbe sličnosti jezika, odgovori su transformirani na brojčanu ljestvicu tako da je odgovor ,,jezici su potpuno različiti“ reprezentiran brojem 1, a odgovor , ,jezici su jako slični“ reprezentiran brojem 4 , čime se ostvaruje mogući raspon rezultata od 1 do 4 .

Možemo uočiti da u svim zadacima koji se tiču talijanskog jezika, učenici koji uče talijanski jezik postižu bolje rezultate od učenika koji uče talijanski i francuski jezik. Statistička značajnost tih razlika bit će prikazana kasnije u radu. Kod zadatka prijevoda s nastavcima, učenici koji uče talijanski i francuski postižu bolje rezultate pri prijevodu na talijanski $(C=2,63$; $S D=$ $1,78)$ nego na francuski $(M=1,69 ; S D=1,40)$. Na zadatku prijevoda fraza učenici koji uče talijanski i francuski postižu istovjetne rezultate pri prijevodu na talijanski $(\mathrm{M}=3,19 ; \mathrm{SD}=1,94)$ i na francuski $(\mathrm{M}=3,19 ; \mathrm{SD}=1,97)$.

Učenici koji uče talijanski i francuski percipiraju najveće sličnosti između talijanskog i francuskog jezika $(M=3,19 ; \mathrm{SD}=1,66)$, a potom između engleskog i francuskog jezika $(M=3,13 ; \mathrm{SD}=0,96)$. Učenici koji uče talijanski $(\mathrm{M}=2,85$; $\mathrm{SD}=0,45)$, kao i učenici koji uče talijanski i francuski $(\mathrm{M}=2,94$; $\mathrm{SD}=0,85)$ procjenjuju sličnost engleskog i talijanskog donekle nižom od procijenjene sličnosti francuskog s engleskim i talijanskim jezikom (v. tablica 6.).

Tablica 6. Deskriptiona statistika ispitivanih kontinuiranih varijabli

\begin{tabular}{llcccc}
\hline Varijabla & Jezik & M & SD & C & IQR \\
\hline Ukupan rezultat & Talijanski & 7,04 & 1,37 & 8,0 & 2 \\
identifikacije & Talijanski i francuski & 5,81 & 1,80 & 6,0 & 2 \\
\hline Ukupan rezultat & Talijanski - prijevod na tal. & 4,12 & 1,82 & 5,0 & 2 \\
prijevoda s & Talijanski i francuski - prijevod na tal. & 2,63 & 1,78 & 2,0 & 4 \\
nastavcima & Talijanski i francuski - prijevod na fr. & 1,69 & 1,40 & 2,0 & 3 \\
\hline Ukupan rezultat & Talijanski - prijevod na talijanski & 5,56 & 2,59 & 6,0 & 3 \\
prijevoda bez & Talijanski i francuski - prijevod na tal. & 3,19 & 1,94 & 3,5 & 3 \\
nastavaka & Talijanski i francuski - prijevod na fr. & 3,19 & 1,97 & 3,0 & 4 \\
\hline Ukupan rezultat & Talijanski & 3,45 & 0,93 & 4,0 & 1 \\
prijevoda fraza & Talijanski i francuski & 2,88 & 1,50 & 3,5 & 2 \\
\hline Usporedba sličnosti & Talijanski (N = 82) & 2,85 & 0,45 & 3,0 & 0 \\
engl. i tal. & Talijanski i francuski & 2,94 & 0,85 & 3,0 & 0 \\
\hline Usporedba sličnosti engleskog i francuskog & 3,13 & 0,96 & 3,0 & 1 \\
\hline Usporedba sličnosti talijanskog i francuskog & 3,19 & 0,66 & 3,0 & 1 \\
\hline Legenda: M - aritmetička sredina, SD - standardna devijacija, C- medijan, IQR - interkvartilno \\
raspršenje.
\end{tabular}

Kako bi se utvrdile statističke značajnosti razlika u ukupnim rezultatima na različitim zadacima između učenika koji uče talijanski te učenika koji uče talijanski i francuski jezik, provedeni su Mann-Whitney U testovi. 
Parametrijski t-testovi za nezavisne uzorke nisu provedeni jer su distribucije rezultata pri svakoj usporedbi za barem jednu podskupinu statistički značajno odstupale od normaliteta, što je utvrđeno Kolmogorov-Smirnov testovima $(\mathrm{KS}<, 05)$ te vizualnom inspekcijom distribucija.

Učenici koji uče talijanski jezik postižu statistički značajno više rezultate od učenika koji uče talijanski i francuski na zadatku identifikacije engleskih riječi koje imaju sličan oblik i na talijanskom jeziku, uz srednje izraženu veličinu efekta $(U=374,5 ; p=, 001 ; r=, 307)$. Na zadatku prijevoda s engleskog na talijanski uz poznate nastavke učenici koji uče talijanski jezik također postižu statistički značajno više rezultate od učenika koji uče talijanski i francuski, uz slabo izraženu veličinu efekta ( $U=384,0 ; p=, 004 ; r=, 279)$. I na zadatku prijevoda s engleskog na talijanski bez poznatih nastavaka učenici koji uče talijanski jezik postigli su statistički značajno više rezultate, uz umjereno izraženu veličinu efekta $(U=322,5 ; p=, 001 ; r=$,333). Razlika na zadatku prijevoda fraza kao i razlika u percepciji sličnosti engleskog i talijanskog jezika nisu se pokazale statistički značajnima (v. tablica 7.).

Tablica 7. Mann-Whitney U test razlika između učenika koji uče talijanski jezik te onih koji uče talijanski $i$ francuski jezik po raznim varijablama

\begin{tabular}{|c|c|c|c|c|c|c|c|}
\hline \multirow{2}{*}{ Zavisna varijabla } & \multicolumn{3}{|c|}{ Normalnost } & \multicolumn{4}{|c|}{ Mann-Whitney U test } \\
\hline & KS & df & $\mathbf{p}$ & $\mathrm{U}$ & $\mathbf{z}$ & p & $\mathbf{r}$ \\
\hline \multirow{2}{*}{ Ukupan rezultat identifikacije } & 0,360 & 85 & $<, 001$ & \multirow{2}{*}{374,5} & \multirow{2}{*}{3,086} & \multirow{2}{*}{,001 } & \multirow{2}{*}{,307 } \\
\hline & 0,229 & 16 &, 024 & & & & \\
\hline \multirow{2}{*}{ Ukupan rezultat prijevoda s nastavcima } & 0,204 & 85 & $<, 001$ & \multirow{2}{*}{384,0} & \multirow{2}{*}{2,803} & \multirow{2}{*}{,004 } & \multirow{2}{*}{,279 } \\
\hline & 0,262 & 16 & ,004 & & & & \\
\hline \multirow{2}{*}{$\begin{array}{l}\text { Ukupan rezultat prijevoda bez } \\
\text { nastavaka }\end{array}$} & 0,131 & 85 & ,001 & \multirow{2}{*}{322,5} & \multirow{2}{*}{3,346} & \multirow{2}{*}{,001 } & \multirow{2}{*}{,333 } \\
\hline & 0,162 & 16 & 200 & & & & \\
\hline \multirow{2}{*}{ Ukupan rezultat prijevoda fraza } & 0,394 & 85 & $<, 001$ & \multirow{2}{*}{541,0} & \multirow{2}{*}{1,517} & \multirow{2}{*}{ 133 } & \multirow{2}{*}{,151 } \\
\hline & 0,283 & 16 & 001 & & & & \\
\hline \multirow{2}{*}{ Usporedba sličnosti eng. i tal. } & 0,470 & 82 & $<, 001$ & \multirow{2}{*}{556,5} & \multirow{2}{*}{1,361} & \multirow{2}{*}{ 221 } & \multirow{2}{*}{ 135 } \\
\hline & 0,404 & 16 & $<, 001$ & & & & \\
\hline
\end{tabular}

Legenda: KS - rezultat Kolmogorov-Smirnov testa, df - stupnjevi slobode, U - rezultat MannWhitney $\mathrm{U}$ testa, $\mathrm{z}$ - z-vrijednost $\mathrm{U}$ testa, $\mathrm{p}$ - statistička značajnost testova, $\mathrm{r}$ - veličina efekta.

Kruskal-Wallis $\mathrm{H}$ testovima učenici su uspoređeni po uratku na različitim zadacima s obzirom na to pohađaju li 6., 7. ili 8. razred. Pronađene su statistički značajne razlike $\mathrm{u}$ rezultatima zadataka identifikacije $(\mathrm{H}(2)=$ $12,91 ; \mathrm{p}=, 002)$, prijevoda s nastavcima $(\mathrm{H}(2)=15,77 ; \mathrm{p}<, 001)$ i prijevoda bez nastavaka $(\mathrm{H}(2)=11,90 ; \mathrm{p}=, 003)$. Nisu nađene statistički značajne razlike $\mathrm{u}$ rezultatima prijevoda fraza $(\mathrm{H}(2)=2,90 ; \mathrm{p}=, 235)$. Mann-Whitney $\mathrm{U}$ post hoc testovima s Bonferroni korekcijom utvrđeno je da učenici 8. razreda postižu lošije rezultate od ostalih razreda na zadacima identifikacije i prijevoda s nastavcima, dok na zadatku prijevoda bez nastavaka učenici 7. razreda postižu bolje rezultate od učenika 6 . razreda. 


\section{RASPRAVA I ZAKLJUČAK}

Rezultati testa pokazuju da postoje razlike između dvije ispitane skupine učenika. Učenici koji uče samo engleski i talijanski u većini su zadataka postigli bolje rezultate od učenika koji uče još i francuski, što govori da prva hipoteza o podjednakim rezultatima obiju skupina nije potvrđena. U istraživanju je također utvrđeno da su učenici nižih razreda općenito postigli bolje rezultate, što se može opravdati brojnim individualnim čimbenicima i istraživanjem J. Cenoz (2001) koje je pokazalo jednak stupanj međujezičnih utjecaja neovisno o dobi učenika. Dobiveni rezultati također nam govore da su učenici koji uče tri strana jezika sporiji u donošenju zaključaka o međujezičnim utjecajima u usporedbi s učenicima koji uče dva strana jezika. $\mathrm{U}$ obzir svakako treba uzeti i značajnu razliku u broju ispitanih učenika u te dvije skupine (talijanski: $\mathrm{N}=85$, talijanski i francuski: $\mathrm{N}=16$ ).

Druga je hipoteza u kojoj pretpostavljamo da su učenici dodatno razvili međujezičnu i metajezičnu svjesnost potvrđena, što pokazuju rezultati testa kao i statistički rezultat da su učenici nakon vođenih i detaljnih uputa te uz pomoć nastavaka razvijali sposobnost promišljanja i analiziranja jezika te svjesno kontrolirali jezičnu uporabu koja je dovela do boljih rezultata. Zadaci su bili izazovni za učenike jer su uspjeli izazvati svjesno leksičko povezivanje engleskog jezika s ostalim jezicima, budući da je engleski jezik uvijek i služio kao osnova za istraživanje procesa ovladavanja drugim jezikom. Pokazali smo da eksplicitnim poučavanjem svjesnosti i strategija možemo utjecati na povećanje razine međujezične i metajezične svjesnosti te da jezično iskustvo učenika trećeg jezika omogućuje njihov veći stupanj koji ima važnu ulogu u olakšavanju ovladavanja jezikom, potiče i ojačava međujezične veze te ukazuje na strategije koje prijenos znanja i iskustava čine jednostavnijim. Učenici su nakon rješavanja takvih zadataka svjesniji povezivanja jezika koje uče, uočavaju sličnosti i razlike među njima, koriste se jezičnim resursima i međujezičnim dodirima i na taj način razvijaju međujezičnu i metajezičnu svjesnost kojom se jačaju mentalne veze te olakšava i obogaćuje proces ovladavanja leksikom, a nastavnicima također ovakvo istraživanje služi kao poticaj za razvoj takve svjesnosti tijekom nastave.

Možemo zaključiti da je leksički prijenos u ovladavanju većim brojem jezičnih sustava isprepleten proces u kojemu do izražaja povremeno dolaze svi mehanizmi, i oni iz J1, i oni iz J2, J3, J4 itd. koji se ne tiču samo leksika nego i brojnih psiholoških i socioloških čimbenika: faktora dobi, motivacije, spremnosti na komunikaciju, straha od jezika, strategija, akulturacije i slično, zbog čega individualizirani pristup učenicima postaje nužan ako uzmemo u obzir da su ti čimbenici različiti od učenika do učenika. Stoga na nastavu trećega jezika treba gledati iz različitih aspekata, što podrazumijeva kombinaciju spontanog i intelektualnog, tj. mehaničkog i kognitivnog pristupa te uklanjanje straha i nelagode pred nerješivim zadacima, zadovoljstvo zbog 
postignutog uspjeha, natjecanje kao faktor stimulacije, element igre u nastavi, odnos između nastavnika i učenika, raznolikost $u$ radu.

Uloga je nastavnika iznimno važna zbog poticanja na analitički pristup učenju jezika uz korištenje ostalih jezika kao izvora znanja i motivacije $u$ ovladavanju novim jezicima. To znači da je potrebno njegovati pozitivan stav prema višejezičnosti $u$ formalnom obrazovanju i poticati učenike na njezino razvijanje kreiranjem kurikula u kojima treba jasno ukazati na poučavanje stranih jezika kroz prizmu i materinskog i ostalih stranih jezika, o čemu treba voditi računa i u osmišljavanju godišnjih planova i programa te udžbenika. Učenicima treba pomoći u razvijanju senzibiliteta za otkrivanje sličnosti između jezika koje trenutačno uče i onih jezika kojima već vladaju. Oni bi trebali razviti višejezični model razmišljanja o jeziku uopće, a ne da budu isključivo usmjereni na ono što $u$ određenom trenutku uče iz jednog jezika. Poticanjem višejezičnog pristupa nastavnik postaje dio razreda, više nije jezično najmoćnija osoba, jer su učenici u engleskom ponekad spretniji. Time se suvremena škola približila potrebama i stvarnom životu mladih te je na taj način ponudila raznovrsne obrazovne mogućnosti i aktivnosti.

Svakim dodavanjem novog jezika u učenički jezični repertoar, istraživanje leksika poprima nove izazove, ali i niz poteškoća s kojima se susreću istraživači, ponajprije ispreplitanjem niza čimbenika, što potvrđuje i ovo istraživanje koje može otvoriti put budućim razjašnjenjima međujezičnih utjecaja u čemu prijedlozi Jajić Novogradec (2007: 232) mogu znatno pomoći: „...usmjeravanje na sličnice isključivo između dva jezika, jer svakim uključivanjem sličnica u tri jezika ili više njih, stvar postaje složenija i teško je doći do pravog izvora utjecaja, upotrebljavati istovremeno više različitih metoda u provjeravanju međujezičnih utjecaja ili kombinirati metode, dodatno ispitivati svjesnost učenika o postojanju sličnica, tj. koliko su svjesni o različitostima među jezicima, uključiti u istraživanje manji broj ispitanika u svrhu dobivanja konkretnijih značajki svakog pojedinca."

U našem se istraživanju između ostalog nastojalo potaknuti učenike na povezivanje i istraživanje $u$ okvirima prijedloga nove reforme obrazovanja koja osobito naglašava samostalan rad učenika, njihov stvaralački rad, uvođenje $u$ istraživačku nastavu, razvijanje sposobnosti za rješavanje problema upotrebom suvremenih nastavnih metoda. Istraživačka nastava doprinosi zadovoljstvu učenika zbog povećanih aktivnosti tijekom nastave i suradnje s ostalim učenicima. Takva nastava doprinosi i boljoj usvojenosti sadržaja i primjeni stečenih znanja. Staru izreku „Reci mi zaboravit ću, pokaži mi zapamtit ću, uključi me i razumjet ću" možemo primijeniti i danas jer nam je cilj razviti istraživačke vještine čime se ostvaruje i važan cilj nove obrazovne reforme međupredmetnom temom „Učiti kako učiti“.

Svakako je prednost to što se osim engleskog jezika još uvijek kod mlađih učenika javlja i postoji interes za učenje ostalih stranih jezika. Nadajmo se da će se u budućnosti ta motivacija još i povećati, a kod nastavnika rasti potreba 
za višejezičnim pristupom, kako bi se i ostali strani jezici nastavili učiti i na fakultetima, možda i ne samo kao izborni predmeti, što je slučaj u većini škola.

Ovo je istraživanje pokazalo da engleski jezik može utjecati na usvajanje talijanskog i francuskog jezika, štoviše, može ga olakšati uz korištenje višejezičnih kompetencija čemu pridonosi činjenica o leksičkim sličnostima tih triju jezika zahvaljujući neprestanim kontaktima tijekom stoljeća. Otvorilo je nova razmišljanja i zanimanje za dodatnim provjeravanjem nekih ključnih čimbenika (jezičnog znanja, skorašnjosti, izloženosti jezicima, motivacije, međujezične i metajezične svjesnosti, jezične nadarenosti, neurološke osnove dvojezičnosti i višejezičnosti) u području međujezičnih utjecaja. Mogli bismo reći da je u našim školama malo pozornosti posvećeno redoslijedu učenja. Stoga bi simultano učenje dva druga strana jezika u ovoj dobi možda mogao biti poticaj za daljnja istraživanja i temeljitiji pristup višejezičnoj hrvatskoj politici.

Ako podržimo konstruktivističku teoriju učenja koja ističe važnost nadogradnje novih znanja na predznanje, i to ne samo kognitivnu (spoznajnu) domenu, već cjelokupno iskustvo pojedinca, uključujući emocije, stavove i vrijednosti, i shvatimo da kvalitetno poučavanje kreće od predznanja, tada ćemo nova znanja povezivati s ostalim stranim jezicima i kulturama koji su učeniku poznati. Prema tome, učenike bi trebalo poticati da nepoznate riječi i izričaje prvo pokušaju razumjeti primjenom postojećega znanja, da prve jezike koriste kao resurse u učenju, što je ključni temelj razvoja individualne višejezičnosti čemu teži europsko društvo.

\section{LITERATURA}

Candelier i sur. (2012) CARAP / FREPA: Cadre de Référence pour les Approches Plurielles des Langues et des Cultures. https://carap.ecml.at/Portals/11/documents/CARAP-FR-web.pdf (14. 10. 2019.).

Cenoz, J. (2001) The Effect of Linguistic Distance, L2 Status and Age on Cross-linguistic Influence in Third Language Acquisition: Psycholinguistic Perspectives. U Cenoz, J., Hufeisen, B. i Jessner, U. (ur.) Cross Linguistic Influence in Third Language Acquisition. Clevedon, Buffalo, Toronto i Sydney: Multilinugal Matters, 8-20.

De Angelis, G. (2007) Third or additional language acquisition. Clevedon, Buffalo, Toronto i Sydney: Multilingual Matters.

Encyklopedia Britannica: English language. https://www.britannica.com/topic/English-language (16. 10. 2019.).

Enciclopedia dell'italiano. Treccani, 2010. http://www.treccani.it/enciclopedia/italiano-in-europa_\%28Enciclopedia-dell\%27Italiano\%29/ (16.1. 2020.).

Eurydice i Eurostat (2012) Ključni podaci o poučavanju jezika u školama u Europi 2012. Bruxelles: Izvršna agencija za obrazovanje, audiovizualnu politiku i kulturu. https://publications.europa.eu/hr/publication-detail/-/publication/48511862-d614-4dc2-8b9a-511ed6d1a7d1/language-hr (14. 10. 2019.).

Europska komisija/EACEA/Eurydice (2017) Ključni podaci o poučavanju jezika u školama u Europi izdanje 2017. Izvješće Eurydicea. Ured za publikacije Europske unije u Luksemburgu. https:// op.europa.eu/en/publication-detail/-/publication/ff10cc21-aef9-11e7-837e-01aa75ed71a1/language-hr/format-PDF

Eurostat (2015) https://www.srednja.hr/zbornica/hrvatski-srednjoskolci-vrhu-eu-a-po-ucenjustranih-jezika-necete-vjerovati-koliko-ih-uci-minimalno-dva/

Europsko vijeće, Zaključci (Obrazovanje i kultura:3), 14. prosinca 2017. https://www.consilium.europa.eu/hr/meetings/european-council/2017/12/14-15/ (14. 10. 2019.). 
Grzega J. (2005) The Role of English in Learning and Teaching European Intercomprehension Skills. Journal for EuroLinguistiX (ELIX) 2, 1-18.

Häusler, M. (2000) Obrazovni koncepti i didaktika višejezičnosti. Strani jezici 29 (1-2), 43-56.

Herdina, Ph. i Jessner, U. (2002) A Dynamic Model of Multilingualism. Perspectives of Change in Psycholinguistics. Clevedon itd: Multilignual Matters Ltd.

Hufeisen, B. i Neuner, G. (2004) The Plurilingualism Project: Tertiary Language Learning - German after English. Goethe-Institut, European Centre for Modern Languages, Council of Europe Publishing.

Jajić Novogradec (2017) Međujezični utjecaji u ovladavanju engleskim leksikom - uloga skorašnjosti i jezičnoga znanja. Neobjavljeni doktorski rad. Zagreb: Filozofski fakultet.

Jelaska, Z. (2005) Ovladavanje drugim jezikom. U Jelaska, Z. i sur. (ur.) Hrvatski kao drugi i strani jezik. Zagreb: Hrvatska sveučilišna naklada, 88-107.

Jelaska, Z. (2005) Hrvatski u višejezičnosti. U Jelaska, Z. i sur. (ur.) Hrvatski kao drugi i strani jezik. Zagreb: Hrvatska sveučilišna naklada, 277-285.

Jessner, U. (2008) A DST Model of Multilingualism and the Role of Metalinguistic Awareness. The Modern Language Journal, 92 (2), 270-283.

Klein, H. G. (2008) L'anglais, base possible de l'intercompréhension romane? Dans ÉLA. Études de linguistique appliquée 149 (1), 119-128. https://www.cairn.info/revue-ela-2008-1-page-119.htm (14. 10. 2019.).

Letica, S. i Mardešić, S. (2007) Cross linguistic transfer in L2 and L3 production. U Horváth, J. i Nikolov. M. (ur.) UPRT 2007: Empirical studies in English applied linguistics. Pécs: Lingua Franca Csoport, 307-318.

Lujić, R. (2017) Utjecaj višejezičnog pristupa na sudjelovanje višejezičnih učenika u nastavi trećeg jezika. Neobjavljeni doktorski rad. Zagreb: Filozofski fakultet.

Medved Krajnović, M. (2010) Od jednojezičnosti do višejezičnosti: Uvod u istraživanja procesa ovladavanja inim jezikom. Zagreb: Leykam international d.o.o.

Meissner, F.J. (2004) Modelling plurilingual processing and language growth between intercomprehensive languages: Towards the analysis of plurilingual language processing $\mathrm{U}$ Zybatow, $\mathrm{N}$. L. (ur.) Translation in der globalen Welt und neue Wege in der Sprach - und Übersetzerausbildung. (Innsbrucher Ringvorlesung zur Translationswissenschaft II). Frankfurt a.M.: Peter Lang, 31-57.

Mihaljević Djigunović, J. (2013) Multilingual attitudes and attitudes to multilingualism in Croatia. U Singleton, D., Fishman J. A., Aronin, L. i Laoire, M. Ó. (ur.) Current multilingualism. A new linguistic dispensation. Boston i Berlin: De Gruyter Mouton, 163-186.

Milambiling, J. (2011) Bringing One Language to Another: Multilingualism as a Resource in the Language Classroom. English teaching Forum 49 (1),18-35.

Nacionalni kurikulum nastavnoga predmeta Talijanski jezik (2019). Zagreb: MZOŠ. https:// narodne-novine.nn.hr/clanci/sluzbeni/2019_01_7_139.html (16. 10. 2019.).

Neuner, G. (2004) The concept of plurilingualism and tertiary language didactics. U Hufeisen, B i Neuner, G. (ur.) The Plurilingualism Project: Tertiary Language Learning - German after English. Strasbourg: Council of Europe, 13-34.

Pavličević-Franić, D. (2006) Jezičnost i međujezičnost između sustava, podsustava i komunikacije. LAHOR 1, 1-14.

Prebeg - Vilke, M. (1977) Uvod u glotodidaktiku. Zagreb: Školska knjiga.

Robert J-M. (2008) L'anglais comme langue proche du français? Dans ÉLA. Études de linguistique appliquée 149, 9-20. https://www.cairn.info/revue-ela-2008-1-page-9.htm (16. 10. 2019.).

Selinker, L. (1972) Interlanguage. International Review of Applied Linguistics 10 (1-4), 209-232.

Tekavčić, P. (1970) Uvod u vulgarni latinitet. Zagreb: Sveučilište u Zagrebu.

ThoughtCo. Terms of Enrichment: How French Has Influenced English. https://www.thoughtco. com/how-french-has-influenced-english-1371255 (16. 10. 2019.).

Vijeće Europe (2005) Zajednički europski referentni okvir za jezike: učenje, poučavanje i vrednovanje. Zagreb: Školska knjiga. 


\section{CROSSLINGUISTIC INFLUENCE OF ENGLISH ON LEARNING ITALIAN AND FRENCH IN CROATIAN ELEMENTARY SCHOOLS}

The paper deals with the study of the crosslinguistic influence of English on the acquisition of Italian and French. The main objective of the paper was to examine the relationship and influence of English as a first foreign language (L2) on the acquisition of Italian and French as a second or third foreign language (L3/L4) in order to encourage multilingualism through linking the existing knowledge of English with that of Italian and French. At the center of the research are two groups of students in elementary school with Croatian as a mother tongue (J1), English as a first foreign language (J2) and Italian and French as a second and third foreign languages, which they have studied simultaneously since the fourth grade. The paper consists of a theoretical and research part. The students of the sixth, seventh and eighth grade took part in the research. The results obtained for students who are learning English and Italian were different from those who are also learning French. The paper has served both as an incentive for research and independent learning, aiming at the development of the crosslinguistic awareness and lifelong learning as part of the new education reform.

Keywords: crosslinguistic influence, first, second and third foreign language, multilingualism, cognates, crosslinguistic awareness, interlanguage, research learning and lifelong learning. 


\section{PRILOG 1}

\section{Zadaci za učenike koji uče talijanski jezik kao drugi strani jezik}

1. U odlomku podcrtaj 8 riječi koje misliš da su slične u talijanskom jeziku (osim riječi Internet i computer), prepiši ih i pokušaj prevesti na talijanski jezik:

The Internet has changed society and is an important part of most homes today. We can communicate with people all over the world and quickly find information we need. We can learn about other cultures and countries we might never visit. It is even possible to find job on the Internet.

1.

2.

3.

4 .

2. Prevedi riječi na talijanski jezik uz pomoć sljedeće tablice i provjeri svoje odgovore iz prvog zadatka:

\begin{tabular}{|l|l|}
\hline \multicolumn{1}{|c|}{ ENGLESKI } & \multicolumn{1}{c|}{ TALIJANSKI } \\
\hline liberty & libertà \\
\hline brilliant & brillante \\
\hline art & arte \\
\hline to illustrate & illustrare \\
\hline attention & attenzione \\
\hline temperature & temperatura \\
\hline to present & presentare \\
\hline terrible & terribile \\
\hline
\end{tabular}

\begin{tabular}{|l|l|}
\hline \multicolumn{1}{|c|}{ ENGLESKI } & \\
\hline society & \\
\hline important & \\
\hline part & \\
\hline to communicate & \\
\hline information & \\
\hline cultures & \\
\hline to visit & \\
\hline possible & \\
\hline
\end{tabular}


3. Prevedi riječi na talijanski jezik:

\begin{tabular}{|l|l|}
\hline \multicolumn{1}{|c|}{ ENGLESKI } & \\
\hline animal & \\
\hline force & \\
\hline curious & \\
\hline excursion & \\
\hline geography & \\
\hline extraordinary & \\
\hline television & \\
\hline communicative & \\
\hline action & \\
\hline professor & \\
\hline
\end{tabular}

4. Pronađi točne odgovore $\mathrm{u}$ tekstu i ispravi svoje odgovore $\mathrm{u}$ tablici:

Il mio cane Gigi è un animale molto curioso. La settimana scorsa sono andato a fare un'escursione in Italia con il professore di geografia. Gigi si annoiava. Mentre giocava, ha preso con forza il telecomando e ha acceso la televisione. C'era un film d'azione. Ha guardato la TV tutto il giorno. Gigi è un cane straordinario e comunicativo.

5. Prevedi sljedeće rečenice na engleski jezik:

C'è una ragazza in classe.

Ci sono due libri sul tavolo. -

Io sto parlando a te.

Io parlo italiano.

6. Poveži engleske i talijanske oblike i provjeri jesi li ih točno upotrijebio $u$ prethodnom zadatku:

I'm going... (present continuous) a

to

I go... (present simple)

there is

there are c'è

Io sto andando... (stare + gerundio)

ci sono

Io vado... (presente)

\section{Zaokruži:}

Engleski i talijanski su: a) jako slični b) slični c) različiti d) potpuno različiti 


\section{PRILOG 2}

\section{Zadaci za učenike koji uče talijanski i francuski jezik kao drugi strani jezik}

1. U odlomku podcrtaj 8 riječi koje misliš da su slične u talijanskom i francuskom jeziku (osim riječi Internet i computer), prepiši ih i pokušaj prevesti na talijanski jezik i francuski jezik:

The Internet has changed society and is an important part of most homes today. We can communicate with people all over the world and quickly find information we need. We can learn about other cultures and countries we might never visit. It is even possible to find job on the Internet.

1.

2.

3.

4.

5.

6.

7.

8.
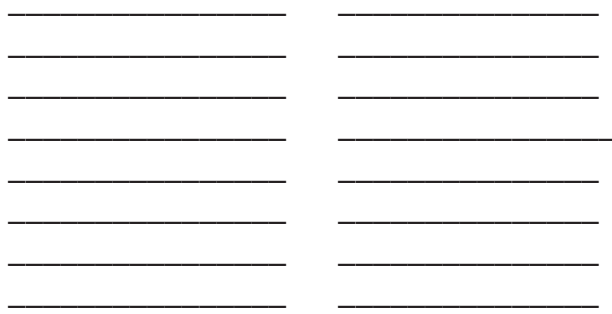

2. Prevedi riječi na talijanski i francuski jezik uz pomoć sljedeće tablice i provjeri svoje odgovore iz prvog zadatka:

\begin{tabular}{|l|l|l|}
\hline \multicolumn{1}{|c|}{ ENGLESKI } & \multicolumn{1}{c|}{ TALIJANSKI } & FRANCUSKI \\
\hline liberty & libertà & liberté \\
\hline brillant & brillante & brillant \\
\hline art & arte & art \\
\hline to illustrate & illustrare & illustrer \\
\hline attention & attenzione & attention \\
\hline temperature & temperatura & temperature \\
\hline to present & presentare & presenter \\
\hline terrible & terribile & terrible \\
\hline
\end{tabular}

\begin{tabular}{|l|l|l|}
\hline \multicolumn{1}{|c|}{ ENGLESKI } & TALIJANSKI & FRANCUSKI \\
\hline society & & \\
\hline important & & \\
\hline part & & \\
\hline to communicate & & \\
\hline information & & \\
\hline culture & & \\
\hline to visit & & \\
\hline possible & & \\
\hline
\end{tabular}


3. Prevedi riječi na talijanski i francuski jezik:

\begin{tabular}{|l|l|l|}
\hline \multicolumn{1}{|c|}{ ENGLESKI } & TALIJANSKI & FRANCUSKI \\
\hline animal & & \\
\hline force & & \\
\hline curious & & \\
\hline excursion & & \\
\hline geography & & \\
\hline extraordinary & & \\
\hline television & & \\
\hline communicative & & \\
\hline action & & \\
\hline professor & & \\
\hline
\end{tabular}

4. Pronađi točne odgovore $\mathrm{u}$ talijanskom $\mathrm{i}$ francuskom tekstu i ispravi svoje odgovore u tablici:

Il mio cane Gigi è un animale molto curioso. La settimana scorsa sono andato a fare un'escursione in Italia con il professore di geografia. Gigi si annoiava. Mentre giocava, ha preso con forza il telecommando e ha acceso la televisione. C'era un film d'azione. Ha guardato la TV tutto il giorno. Gigi è un cane straordinario e comunicativo.

Mon chien Gigi est un animal très curieux. La semaine dernière je suis allé en excursion en Italie avec le professeur de géographie. Gigi s'ennuyait. Pendant qu'il jouait, il a pris avec force la télécommande et a allumé la télévision. Il y avait un film d'action. Il a regardé la télé toute la journée. Gigi est un chien extraordinaire et communicatif.

5. Prevedi sljedeće rečenice na engleski jezik:

C'è una ragazza in classe.

Ci sono due libri sul tavolo. -

Io sto parlando a te.

Io parlo italiano.

6. Poveži engleske i talijanske oblike i provjeri jesi li ih točno upotrijebio $u$ prethodnom zadatku:

I'm going... (present continuous) to

a

I go... (present simple)

c'è

there is

Io sto andando... (stare + gerundio)

there are

ci sono

Io vado... (presente)

7. Koji francuski oblik odgovara talijanskim oblicima $c^{\prime} e$ - ci sono i engleskim there is - there are?

Uz pomoć traženog oblika prevedi prvu rečenicu iz 5. zadatka na francuski jezik! 


\section{Zaokruži:}

Engleski i talijanski su: a) jako slični b) slični c) različiti d) potpuno različiti Engleski i francuski su: a) jako slični b) slični c) različiti d) potpuno različiti Talijanski i francuski su: a) jako slični b) slični c) različiti d) potpuno različiti 